\title{
KEPEMIMPINAN NON-MUSLIM DALAM PERSPEKTIF IMAM AL-MAWARDI (KAJIAN LITERATUR KITAB AL- AHKAM AS-SULTHANIYYAH)
}

\author{
Evan Edo Prasetya \\ Universitas Ibn Khaldun \\ Email: evanedobogor17@gmail.com \\ Yono \\ Universitas Ibn Khaldun \\ Email: yono@fai.uika-bogor.ac.id \\ Sutisna \\ Universitas Ibn Khaldun \\ Email: sutisna@fai.uika-bogor.ac.id
}

\begin{abstract}
This paper tries to discover out the views of Imam al-Mawardi about the leadership of a nonmuslim as expressed in his book titled Al-Ahkam As-Sulthaniyyah. This paper based on philosophical approach. The philosophical approach applied to investigate the views of Imam alMawardi. The primary data sources collected from the book Al-Ahkam As-Sultaniyyah, while secondary data are books to review al-Mawardi's thoughts, as well as articles, writings and journals related to the research topic. The results of the study show that the concept of leadership of a non-Muslim according to Imam al-Mawardi is to forbid a non-Muslim from taking up a position as a leader, head of state or government. Because it is against Islamic law. However, Imam alMawardi granted a non-Muslim to take up a position particularly as a vizier or at the level of minister or assistant.
\end{abstract}

Keywords: Leadership, Non-Muslim, Imam al-Mawardi.

\begin{abstract}
Abstrak
Artikel ini bertujuan untuk mengetahui pandangan Imam al-Mawardi tentang kepemimpinan seorang non-muslim yang termaktub dalam kitabnya yang berjudul Al-Ahkam As-Sulthaniyyah. Artikel ini merupakan kajian kepustakaan yang dikaji berdasarkan pendekatan filosofis. Pendekatan filosofis digunakan untuk mengkaji pemikiran tokoh Imam al-Mawardi. Sumber data primer berasal dari kitab Al-Ahkam As-Sultaniyyah, sedangkan data sekunder berupa buku-buku yang ditulis untuk membedah pemikiran al- Mawardi, serta artikel, tulisan dan jurnal yang berhubungan dengan topik penelitian. Hasil kajian menunjukkan bahwa konsep kepemimpinan seorang non-muslim menurut Imam al-Mawardi adalah melarang seorang non-muslim menduduki jabatan sebagai pemimpin, kepala negara atau kepala pemerintahan. Sebab, bertentangan dengan syariat Islam. Namun demikian, Imam al-Mawardi membolehkan seorang non-muslim untuk menduduki jabatan hanya sebagai wazir atau setingkat menteri atau pembantu.
\end{abstract}

Kata Kunci: Kepemimpinan, Non-Muslim, Imam al-Mawardi. 
Evan Edo Prasaetyo, Yono \& Sutisna

Kepemimpinan Non-Muslim Dalam Perspektif...

\section{Pendahuluan}

Artikel ini berangkat dari studi yang dilakukan Muh Yaqub Khan tentang legitimasi politik pemikiran Imam al-Mawardi dari Arabic \& Middle Eastern Studies, University of Leeds ${ }^{1}$ Legitimasi politik yang diberikan perhatian Khan, salah satunya adalah perhatiannya kepada pemikiran terbuka Imam al-Mawardi yang memberikan intrepetasi adanya ruang bagi non-muslim untuk menduduki jabatan pemerintahan. Studi ini juga diperkuat oleh kajian yang dilakukan Rahmawati ${ }^{2}$ dan Ahmad Fauzan. ${ }^{3}$

Beberapa kajian yang dilakukan tersebut dijadikan pijakan untuk mendaur ulang ruang pengetahuan dalam konteks realitas bangsa Indonesia yang majemuk. Apalagi fenomena publik seringkali non-muslim menjadi perhatian di tengah masyarakat Indonesia yang mayoritas muslim. Kerapkali masalah relasi sosial kepemimpinan menjadi masalah publik yang mengkristal sejak D.K.I Jakarta dipimpin oleh Basuki Tjahja Purnama yang non-muslim menjadi Gubernur pada tahun 2014-2017. Kristalisasi ini menyebar karena tidak sedikit daerah di Indonesia yang mempunyai pimpinan kepala daerah dari non-muslim seperti Bali, Ambon, Manado, dan Papua, serta Pontianak dan daerah lainnya. Studi sebelumnya yang disebutkan pada awal pendahuluan ini kemudian mendapat ruang fenomena untuk dikaji berdasarkan perspektif Imam-al Mawardi dalam konteks kepemimpinan seorang non-muslim sehingga menjadi pengetahuan bagi pembaca jurnal ini.

Pemimpin adalah penentu bagi kesejahteraan rakyat. Dalam kehidupan, pemimpin ibarat kepala dari seluruh anggota tubuh. Pemimpin memiliki peranan yang strategis dalam pengaturan pola dan gerakan. Kecakapannya dalam memimpin akan mengarahkan umatnya kepada tujuan yang ingin dicapai, yaitu kejayaan dan kesejahteraan umat dengan diiringi ridha Allah swt. Seperti dalam Q.S Al-Baqarah ayat 207.

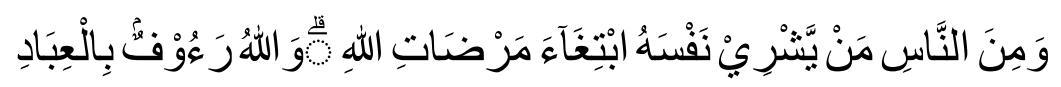

Terjemahnya: "Dan di antara manusia ada orang yang mengorbankan dirinya karena mencari keridhaan Allah, dan Allah maha penyantun kepada hamba-hambanya."4

1 Mohammad Yaqub Khan, A Political Study of Al-Mawardi with Special Reference to the Concept of Legitimicay, (Leeds: University of Ledds, 2001). 128.

2 Rahmawati, "Sistem Pemerintahan Islam Menurut Al-Mawardi dan Aplikasinya di Indonesia", Jurnal Syari ah dan Hukum 16.no. 2 (2018): 264-283

3 Ahmad Fauzan, "Leadership Character According To Imam Al-Mawardi And Its Relevance In Indonesia: The Study Of The Book Of Al-Ahkam As-Sulthaniyyah", Jurnal Penelitian, 15 no.01 (2018): 39-50.

4 Al-Qur'an dan Terjemahannya, (Jakarta: Departemen Agama RI, 1987)

DIKTUM: Jurnal Syariah dan Hukum Volume 19 Nomor 1 Juli 2021 
Evan Edo Prasaetyo, Yono \& Sutisna

Kepemimpinan Non-Muslim Dalam Perspektif...

Islam mengajarkan bahwa seorang pemimpin menempati posisi yang sangat penting terhadap perjalanan umatnya. Apabila sebuah jama'ah memiliki seorang pemimpin yang prima, serta punya keahlian dalam membangkitkan daya juang, maka dapat dipastikan perjalanan umatnya akan mencapai titik keberhasilan. Sebaliknya, jika suatu jama'ah dipimpin oleh seorang yang memiliki banyak kelemahan, serta lebih mengutamakan hawa nafsu dalam mengambil keputusan, maka dapat dipastikan umat tersebut akan mengalami kemunduran, dan bahkan mengakami kehancuran. Hal tersebut sesuai dengan Q.S al-Isra ayat 16.

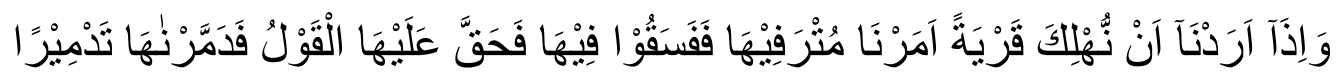

Terjemahnya : “Dan jika kami hendak membinasakan suatu negeri, maka kami perintahkan kepada orang-orang yang hidup mewah di negeri itu (supaya mentaati Allah) tetapi mereka melakukan kedurhakaan dalam negeri itu, maka sudah sepantasnya berlaku terhadapnya perkataan (hukuman kami), kemudian kami hancurkan negeri itu sehancur-hancurnya." 5

Oleh karena itu, Islam memandang bahwa pemimpin memilik posisi yang sangat strategis demi terwujudnya masyarakat yang berada dalam baldatun tayyibatun wa rabbun ghafur. Wujud masyarakat Islami yang menerapkan prinsip-prinsip Islam dalam sistem kehidupannya, sehingga mencapai tingkat kemakmuran dan kesejahteraan yang merata dengan keadilan bagi seluruh masyarakatnya. Allah swt. menggariskan bahwa dalam umat harus ada pemimpin yang menjadi pengganti dan pelanjut fungsi kenabian, menjaga terselenggaranya ajaran agama, dan menyatukan umat dalam kepemimpinan yang tunggal. Kepemimpinan bertugas sebagai pengganti kenabian dalam melindungi agama dan kemaslahatan hidup. Berdasarkan ijma ulama bahwa mengangkat seseorang yang memiliki kredibilitas dalam menjalankan tugas kenegaraan dalam Islam khususnya dalam hal imamah dan wizarat (para pembantu khalifah) dikalangan umat ini adalah wajib meskipun Imam al Asham tidak sependapat dengan mereka. Pemimpin meempati posisi yang penting dalam dalam Islam. Karena pemimpin memegang kebijkan yang berkaitan dengan hajat hidup orang banyak mulai dari kesehatan, transportasi, tata kelola sumber daya alam, kesejahteraan, dan pelbagai kebijakan publik lainnya. ${ }^{6}$

Dalam kitab Al-Ahkam As-Sulthaniyyah karangan Imam al-Mawardi membolehkan jabatan Wazir Tanfidzi (pembantu khalifah bidang administrasi) alias mentri dipegang oleh kafir dzimmi (orang kafir yang berada dalam perlindungan

5 Al-Qur'an dan Terjemahannya.

6 Al-Mawardi. al-Ahkam as-Sulthaniyyah, (Jakarta: Qisthi Press, 2019).

DIKTUM: Jurnal Syariah dan Hukum Volume 19 Nomor 1 Juli 2021 
Evan Edo Prasaetyo, Yono \& Sutisna

Kepemimpinan Non-Muslim Dalam Perspektif...

kaum muslimin). ${ }^{7}$ Pembolehan ini tentu dengan kriteria yang ketat yang disebutkan dengan lengkap oleh Imam al-Mawardi dalam kitabnya yang akan dibahas dalam artikel ini.

\section{Metode}

Jenis penelitian ini adalah kualitatif ${ }^{8}$ dengan metode pengumpulan data kepustakaan yang dikaji berdasarkan pendekatan filosofis. Pendekatan filosofis digunakan untuk mengkaji pemikiran tokoh Imam al-Mawardi. Sumber data primer berasal dari kitab Al-Ahkam As-Sultaniyyah, sedangkan data sekunder berupa bukubuku yang ditulis untuk membedah pemikiran al- Mawardi, serta artikel, tulisan dan jurnal yang berhubungan dengan tema penelitian yang diunduh melalui jejaring internet. Data yang terkumpul kemudian dianalisis dan diberikan makna, serta didiskusikan melalui kajian yang telah dilakukan peneliti sebelumnya tentang pemikiran filosofis Imam al-Mawardi yang berhubungan dengan konsep kepemimpinan bagi non-muslim dalam Islam.

\section{Hasil dan Pembahasan}

\section{Konsep Kepemimpinan}

Dalam perspektif Al-Qur`an, istilah pemimpin yang dikonsepkan dalam kajian syariah dan hukum dapat merujuk pada terminologi khalifah, imamah dan ulu al amr. Menurut bahasa, kata khalifah merupakan subjek dari kata kerja lampau khalafa yang bermakna menggantikan atau menempati tempatnya. Imamah diserap dari kata imam, dalam Maqayis al Lughah dijelaskan bahwa terminologi imam pada mulanya berarti pemimpin shalat. ${ }^{9}$ Imam juga berarti orang yang diikuti jejaknya dan didahulukan urusannya. ${ }^{10}$ Ulu al amr merupakan ungkapan frase nominal yang terdiri atas dua suku kata, ulu dan al amr. Yang pertama bermakna pemilik, dan yang kedua bermakna perintah. Tuntunan melakukan sesuatu dan keadaan atau urusan. ${ }^{11}$

7 Al-Mawardi. 53.

8 Moleong, L.J. Metode Penelitian Kualitatif, (Bandung: Rosdakarya, 2012).

9 Hakim Wahyudi, Hakmi Hidayat \& Sri Wahyuni Hakim. "Pemikiran Gramatikal Bahasa Arab oleh Linguistic Arab (Studi Tokoh Lintas Mahzab Nahwu", Jurnal Ilmiah Keislaman 19 no.19 (2020): 113-128.

10 Zuhri, “Kepemimpinan Profetikdi Era 4.0”, Jurnal Studi Ilmu Keagamaan Islam 1 no.1 (2020):115-135.

11 Surahman Amin \& Ferry Muhammadsyah Siregar, "Pemimpin dan Kepemimpinan Dalam AlQur `an", Tanzil: Jurnal Studi Islam 1 no.1. (2015).6.

DIKTUM: Jurnal Syariah dan Hukum Volume 19 Nomor 1 Juli 2021 
Evan Edo Prasaetyo, Yono \& Sutisna

Kepemimpinan Non-Muslim Dalam Perspektif...

Kata ulu al amr diterjemahkan "pemilik urusan" dan "pemilik kekuasaan" atau "hak memberi perintah". Melalui pengertian ini, ulu al amr disepadankan dalam arti "pemimpin". ${ }^{12}$

Beberapa isitlah pemimpin yang dijelaskan di atas, terdapat dua konstruksi kata yang kerapkali menjadi perhatian masyarakat, yakni khilafah dan ulu al amr. Khalifah kerapkali disebut sebagai Amir al Mu'minin atau pemimpin orang yang beriman. Kata khalifah diungkapkan pula dalam Q.S Al-Baqarah ayat 30. Ayat ini sebagai bentuk penegasan Allah swt. untuk menciptakan manusia sebagai pemimpin.

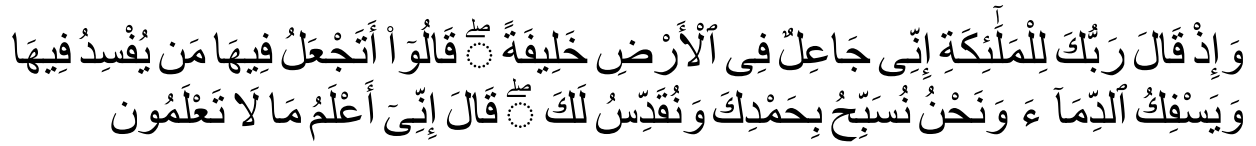

Terjemahnya: "Ingatlah ketika Tuhanmu berfirman kepada para Malaikat: "Sesungguhnya Aku hendak menjadikan seorang khalifah di muka bumi". Mereka berkata: "Mengapa Engkau hendak menjadikan (khalifah) di bumi itu orang yang akan membuat kerusakan padanya dan menumpahkan darah, padahal kami senantiasa bertasbih dengan memuji Engkau dan mensucikan Engkau?" Tuhan berfirman: "Sesungguhnya Aku mengetahui apa yang tidak kamu ketahui". ${ }^{13}$

Sementara itu, Ibn Katsir dalam tafsirnya menyimpulkan bahwa ulu al amr adalah menurut zahirnya ulama. Sedangkan secara umum ulu al amr adalah umara dan ulama. Pengertian dengan term ulu al amr dapat menjadi lebih luas lagi karena mencakup setiap pribadi yang memegang kendali urusan kehidupan, besar ataupun kecil, seperti pemimpin negara, atau pemimpin keluarga, bahkan pemimpin diri sendiri juga termasuk di dalamnya. ${ }^{14}$

\section{Non-Muslim}

Dalam Al-Qur`an, non-muslim disebut sebagai kafir. Penyebutan ini dikarenakan mereka tidak beriman kepada Allah dan rasul. Kata kafir sendiri secara bahasa artiya menutupi sesuatu, melepaskan diri, menghapus atau menyembunikan kebaikan yang telah diterima, dan dari segi akidah kafir berarti kehilangan imam. Sedangkan secara terminologis, Said Hawa memberikan pengertian bahwa kafir adalah orang yang ingkar terhadap kebenaran islam. Istilah kafir dalam Al-Qur`an

12 Surahman Amin \& Ferry Muhammadsyah Siregar.

13 Al-Qur'an dan Terjemahannya, (Jakarta: Departemen Agama RI, 1987)

14 Surahman Amin \& Ferry Muhammadsyah Siregar, "Pemimpin dan Kepemimpinan Dalam AlQur 'an", Tanzil: Jurnal Studi Islam 1 no.1. (2015). 7.

DIKTUM: Jurnal Syariah dan Hukum Volume 19 Nomor 1 Juli 2021 
Evan Edo Prasaetyo, Yono \& Sutisna

Kepemimpinan Non-Muslim Dalam Perspektif...

mengacu pada perbuatan yang berhubungan dengan Allah, namun semua hubungan tersebut bersifat negatif, seperti menginkari nikmat yang diungkapkan dalam surah An Nahl ayat 55 dan lari dari tanggung jawab dalam Q.S Ibrahim ayat 22.

Q.S An-Nahl ayat 55:

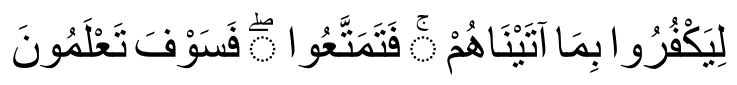

Terjemahnya: "biarlah mereka mengingkari nikmat yang telah kami berikan kepada mereka; maka bersenang-senanglah kamu. Kelak kamu akan mengetahui (akibatnya)."15

Q.S. Ibrahim ayat 22:

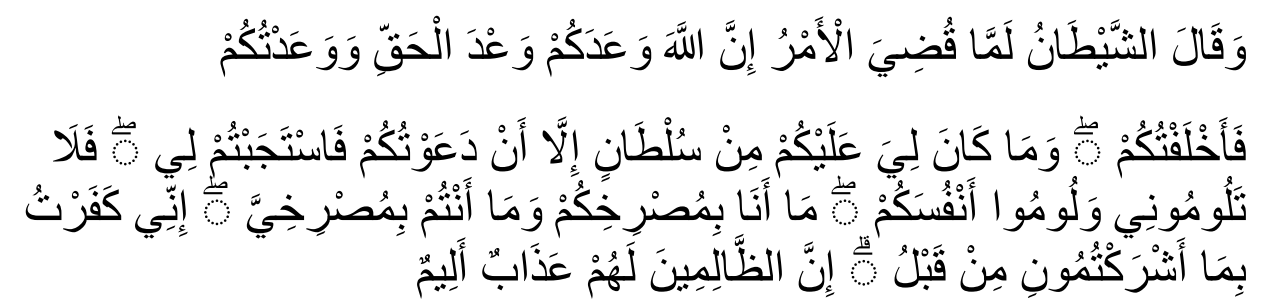

Terjemahnya: “Dan berkata lah syaitan tatkala perkara hisyab telah diselesaikan: sesungguhnya allah telah menjanjikan kepadamu janji yang benar, dan aku pun telah menjanjikan kepadamu tetapi aku menyalahinya. Sekali-sekali tidak ada kekuasaan bagiku terhadapmu, melaikan sekedar aku menyeru kamu lalu kamu mematuhi seruanku, oleh sebab itu janganlah kamu mencerca aku akan tetapi cercalah dirimu sendiri. Aku sekali-kali tidak dapat menolongmu dan kamu pun sekali-kali tidak dapat menolongku. Sesungguhnya aku tidak membenarkan perbuatanmu mempersekutukan aku sajak dahulu. Sesungguhnya orang-orang zalim itu mendapat siksaan yang pedih."16

Penolakan atau pembangkangan terhadap hukum allah, dan meninggalkan amal saleh yang diperintah Allah Swt. Dari 525 kata kafir dalam berbagai derivasinya, arti yang paling dominan adalah pendustaan atau pengingkaran terhadap Allah dan rasul-rasulnya, khususnya kepada nabi Muhammad dan ajaran yang dibawanya.

15 Al-Qur'an dan Terjemahannya, (Jakarta: Departemen Agama RI, 1987) 16 Al-Qur'an dan Terjemahannya, (Jakarta: Departemen Agama RI, 1987)

DIKTUM: Jurnal Syariah dan Hukum Volume 19 Nomor 1 Juli 2021 
Evan Edo Prasaetyo, Yono \& Sutisna

Kepemimpinan Non-Muslim Dalam Perspektif...

Para ulama fikih mengklasifikasikan non-muslim menjadi dua kelompok, yakni ahl al-harb dan ahl al-'ahd. Pembagian ini berdasrkan firman allah swt. dalam Q.S Al Mumtahanah:8-9.

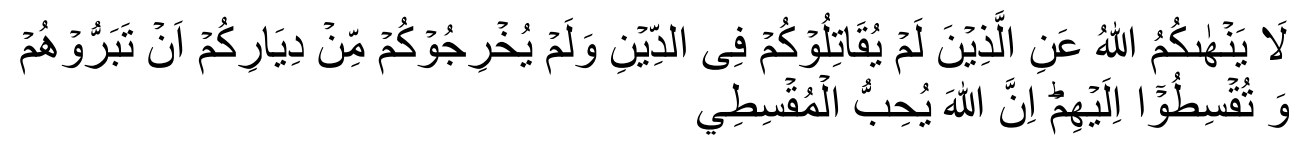

Terjemahnya: (8)“Allah tidak melarang kamu berbuat baik dan berlaku adil terhadap orang-orang yang tidak memerangimu dalam urusan agama dan tidak mengusir kamu dari kampung halamanmu. Sesungguhnya allah mencintai orang-orang yang berlaku adil."

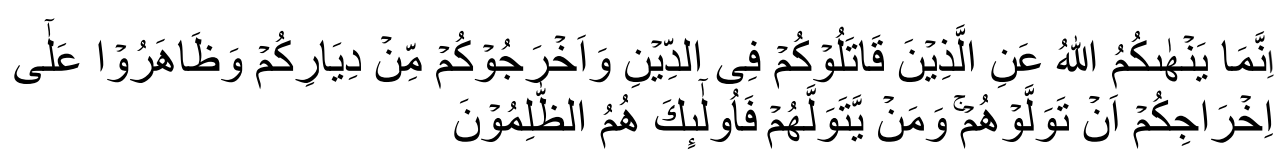

Terjemahnya: (9)“Sesungguhnya allah hanya melarang kamu menjadikan mereka sebagai kawanmu orang-orang yang memerangi kamu dalam urusan agama dan mengusir kamu dari kampung halamanmu dan membantu (orang lain) untuk mengusirmu. Barangsiapa yang menjadikan mereka sebagai kawan, mereka itulah orang-orang yang zalim."

Ahl al harb adalah golongan orang-orang kafir yang memerangi atau terlibat peperangan dengan kaum muslim. Istilah kafir harbi menurut Yusuf al Qardawi disematkan oleh para fukaha kepada golongan non-muslim yang tinggal di wilayah mereka yang disebut dar al harb dan menyatakan permusuhan terhadap kaum muslim dan para pemimpin mereka atau yang tidak mengakui negara Islam. Golongan kafir harbi ini adalah semua orang kafir yang menampakkan permusuhan dan menyerang kaum muslim, baik dari kalangan musyrik (kaum pagan) maupun para ahli kitab.

Sikap kaum muslim terhadap mereka adalah keras disebabkan sikap mereka yang memusuhi dan memerangi Islam. Syaikh Muhammad ibn Shalih al Utsaimin menyatakan, kafir harbi (karena sikap mereka) tidak memiliki hak untuk mendapat perlindungan dan pemeliharaan dari kaum muslim. Mereka inilah golongan orangorang kafir yang diperangi oleh Rasulullah saw. Sementara ahl al-'ahd merupakan orang-orang non-muslim yang bersikap baik, menjalin hubungan yang harmonis terhadap kaum muslim, dan tidak terlibat dalam memusuhi mereka. Golongan ini adalah mereka yang berdamai dan mengadakan ikatan perjanjian dengan kaum muslim, baik yang memilih tinggal di dar al islam (wilayah Islam) maupun yang tetap tinggal di wilayahnya. 
Evan Edo Prasaetyo, Yono \& Sutisna

Kepemimpinan Non-Muslim Dalam Perspektif...

Para fukaha membagi kelompok ahl al-'ahd ini menjadi tiga golongan. Hal ini disebabkan perbedaan sikap dan kedudukan mereka dalam menjalin perjanjian dengan kaum muslim. Mereka adalah ahl al-dzimmah, ahl al hudnah, dan ahl al aman. Ahl al-dzimmah adalah non-muslim yang menjadi tanggungan kaum muslim karena telah mengadakan perjanjian berupa tunduk dan patuh terhadap ketentuan beserta hukum Allah dan rasulnya seraya menunaikan jizyah dan mereka berdiam di wilayah Islam. Golongan ini menjadi tanggungan permanen kaum muslim, mereka dijamin hidup dengan aman, damai, dan mendapatkan hak serta kewajiban yang secara umum sama dengan penduduk muslim lainnya, terutama di bidang sosial (muamalah).

Golongan kedua adalah ahl al hudnah, yaitu non-muslim yang mengadakan perjanjian damai dengan negara Islam. Perbedaan gologan ini dengan ahl al-dzimmah adalah keberadaan mereka yang tidak tinggal di wilayan Islam, namun mengadakan perjanjian dengan kaum muslim. Telah terjadi kesepakan di antara mereka dan kaum muslim untuk tidak berperang dalam kurun waktu yang telah disepakati atau yang biasa dikenal dengan istilah gencatan senjata. Oleh sebab itu, golongan ini tidak menjadi tanggungan kaum muslim, hanya saja kaum muslim memiliki ikatan baik dalam berhubungan dengan mereka. Terhadap kelompok ini umat islam memiliki kewajiban untuk menjaga perjanjian yang telah disepakati oleh kedua belah pihak.

Golongan terakhir adalah ahl al aman, yaitu non-muslim yang tinggal di luar wilayah Islam, namun melakukan kesepakatan perjanjian untuk mendapatkan jaminan keamanan ketika berdiam di dalam wilayah Islam dalam jangka waktu tertentu. Perbedaan golongan ini dengan golongan lainnya adalah keberadaan mereka di wilayah Islam bukan untuk maksud tinggal selamanya, namun dalam jangka waktu yang terbatas atau sementara. Golongan ini biasanya memasuki wilayah Islam dengan maksud untuk berdagang atau para musafir yang menetap dengan waktu yang terbatas. Karena jika mereka akan menetap untuk selamanya, maka status mereka akan berubah menjadi ahl al-dzimmah, sehingga memiliki hak dan kewajiban yang berbeda.

\section{Kedudukan Non-Muslim Dalam Pemerintahan}

Dalam konteks kebergaman serta toleransi dalam Islam, Imam al-Mawardi membolehkan dalam kitab al-Ahkam as-Sulthaniyyah seorang non-muslim menduduki jabatan dalam pemerintahan. Dalam hal ini Imam al-Mawardi menjelaskan seorang non-muslim hanya boleh menduduki jabatan sebagai Wazir Tanfidzi (pembantu khalifah bidang administrasi) dengan catatan jabatan itu hanya boleh dipegang oleh orang kafir dzimmi (orang kafir yang berada dalam perlindungan

DIKTUM: Jurnal Syariah dan Hukum Volume 19 Nomor 1 Juli 2021 
Evan Edo Prasaetyo, Yono \& Sutisna

Kepemimpinan Non-Muslim Dalam Perspektif...

kaum Muslimin). ${ }^{17}$ Sudah barang tentu dengan memperbolehkannya Imam alMawardi terhadap seorang non-muslim untuk menduduki sebuah jabatan dalam pemerintahan dalam hal ini menduduki jabatan sebagai wazir atau setingkat menteri mempunyai berbagai macam pertimbangan antara lain:

a. Wazir Tanfidzi boleh diduduki oleh seorang non muslim adalah karena dalam jabatan ini seorang Wazir Tanfidzi tidak diperbolehkan untuk memutuskan hukum sendiri, menangani kasusu kriminal, dan mengurusi pasukan perang.

b. Tidak diperbolehkan untuk melantik pejabat, karena secara umum Wazir Tanfidzi hanya mengurusi bidang administrasi saja.

c. Tidak diperbolehkan untuk mengomandani pasukan perang dan mengatur strategi perang.

d. Tidak diperbolehkan untuk mengelola harta Baitul Mal (kas Negara), baik dengan cara menyimpan maupun mengeluarkannya.

Selain keempat kewenangan yang tidak boleh dimiliki seperti dijelaskan di atas, orang kafir dzimmi tidak dilarang menduduki kursi wizara, kecuali jika mereka semena-mena yang menyebabkan mereka dilarang menduduki kursi wizara. Di samping itu, antara Wazir Tafwidhi (pembantu khalifah bidang pemerintahan) dan Wazir Tanfidzi (pembantu Khalifah bidang administrasi) juga berbeda di dalam syaratsyarat wizara. Secara garis besar perbedaan d iantara keduanya terbagi menjadi empat.

Pertama, untuk menduduki jabatan Wazir Tafwidhi (pembantu khalifah bidang pemerintahan) disyaratkan harus merdeka, sedangkan untuk menjadi Wazir Tanfidzi (pembantu Khalifah bidang administrasi) tidak disyaratkan demikian. Kedua, untuk menduduki jabatan Wazir Tafwidhi disyaratkan harus beragama Islam, sedangkan untuk jabatan Wazir Tanfidzi tidak disyaratkan demikian. Ketiga, untuk menduduki jabatan Wazir Tafwidhi disyaratkan menguasai ilmu tentang hukum-hukum syariat, sedangkan untuk menjadi Wazir Tanfidzi tidak disyaratkan demikian. Kelima, untuk menduduki jabatan Wazir Tawfidhi disyaratkan memiliki ilmu tentang peperangan atau Kharaj, sedangkan untuk Wazir Tanfidzi tidak disyartkan demikian.

Dari keterangan di atas, dapat ditarik benang merah bahwa dari kedua wazir (pembantu khalifah) di atas terdapat empat perbedaan di dalam syarat-syarat pelantikannya sebagaimana terdapat empat perbedaan juga di dalam wilayah

17 Al-Mawardi. 51-53.

DIKTUM: Jurnal Syariah dan Hukum Volume 19 Nomor 1 Juli 2021 
Evan Edo Prasaetyo, Yono \& Sutisna

Kepemimpinan Non-Muslim Dalam Perspektif...

kewenangan keduanya. Di luar perbedaan tersebut, antara keduanya juga ada kesamaan di dalam hak dan syarat-syarat lainnya.

\section{Pandangan Imam al-Mawardi terhadap Pemimpin Non-Muslim}

Sebagaimana terurai dalam konsep kepemimpinan yang dibahas sebelumnya, pemimpin seringkali merujuk pada ulu al amr atau pejabat, yaitu orang yang mendapat amanah untuk mengurus urusan orang lain dan khadimul umat (pelayan umat) dengan pengertian seorang pemimpin harus menempatkan diri pada posisi sebagai pelayan masyarakat. Pemimpin dalam Islam ada beberapa bentuk, yaitu khalifah, imamah, imarah, wilayah sultan, mulk dan ri'asah. Setiap istilah ini mengandung arti pemimpin secara umum, namun istilah yang sering digunakan Imam al-Mawardi dalam konteks pemimpin pemerintahan dan kenegaraan, yakni imamah.

Menurut Imam al-Mawardi, imamah berfungsi mengganti peranan kenabian dalam memelihara agama dan mengatur dunia. Posisi imamah ini mempunyai implikasi moral untuk berusaha menciptakan kesejahteraan hidup bersama berdasarkan prinsip keadilan dan persamaan. Yang dimaksud oleh Imam al-Mawardi dengan pemimpin adalah imamah, khalifah, raja, sultan atau kepala negara, dan dengan demikian Imam al-Mawardi memberikan juga baju politik. Menurutnya, Allah mengangkat untuk umatnya seorang pengganti Nabi saw., untuk mengamankan agama, dengan disertai mandat politik. Dengan demikian, seorang imam pada satu pihak adalah pemimpin agama, dan dipihak lain adalah pemimpin politik.

Menurut al-Taftazani yang telah dikutip oleh Dhiauddin Rais, dalam bukunya yang berjudul "Teori Politik Islam", keimamahan didefinisiskan sebagai pemimpin umum dalam urusan dunia dan agama. Sebagai khalifah atau wakil dari Nabi saw., definisi tersebut tidak jauh berbeda dengan definisi yang disampaikan oleh Imam alMawardi, dia juga menghimpun urusan agama dan dunia pada kata imamah (pemimpin), itu sebabnya kenapa non-muslim oleh Imam al-Mawardi dilarang menduduki jabatan sebagai Kepala Negara dalam hal ini sebagai khalifah, dikarenakan jabatan ini memikul tugas bukan hanya di dunia bahkan sampai di akhirat kelak.

Imam al-Mawardi juga memberikan syarat-syarat terhadap orang yang berhak dipilih sebagai pemimpin dengan tujuh syarat. Pertama, adil dalam arti yang luas. Kedua, memiliki ilmu untuk melakukan ijtihad di dalam mengahadapi persoalan-persoalan dan hukum. Ketiga, sehat pendengaran, mata, dan lisannya 
Evan Edo Prasaetyo, Yono \& Sutisna

Kepemimpinan Non-Muslim Dalam Perspektif...

supaya dapat berurusan langsung dengan tanggung jawab. Keempat, sehat badan sehingga tidak terhalang untuk melakukan gerak dan melangkah cepat. Kelima, pandai dalam mengendalikan urusan rakyat dan kemaslahatan umum. Keenam, berani dan tegas membela rakyat, wilayah negara dan mengahadapi musuh. Ketujuh, keturunan Quraisy. Ketujuh syarat tersebut harus dipenuhi sebelum seseorang dipilih atau diberi mandat untuk menjabat sebagai kepala negara tau pemimpin. Dalam syarat di atas memang tidak menyebutkan secara jelas bahwa seorang pemimpin harus seorang muslim, namun dengan adanya syarat memiliki ilmu sehingga dapat melakukan ijtihad sudah barang tentu merupakan seorang muslim.

Menurut Rahmawati, pemikiran Imam al-Mawardi dalam sistem pemerintahan yang juga mencakup kepempiminan dan terdapat aturan (rules) dan tanggung jawab (responsibilities) dipandang sangat realisitis dan demokratis untuk diterapkan. Hal ini dikarenakan Imam al-Mawardi memuat kerangka konseptual mengenai penyelenggaraan ketatanegaraan yang ideal berdasarkan permasalahan politik yang muncul pada realitas zamannya melalui apa yang disebut sebagai kontrak sosial dalam konteks muslim dan non-muslim. Dengan kontrak sosial inilah ruang kehidupan politik akan lebih demokratis dan adil. Hal sama dijelaskan Ahmad Fauzan bahwa pemerintahan Islam bukanlah tirani dan bukan kekuasaan mutlak, melainkan konstitusional seperti yang dipahami saat ini. Namun, demikian disarankan bahwa seorang pemimpin berasal dari golongan ulama meskipun di Indonesia merupakan negara yang majemuk, yang terdiri dari berbagai suku, agama dan budaya. Kemudian selanjutnya syarat yang ditawarkan al-Mawardi yang masih kurang relevan adalah bahwa pemimpin harus berasal dari kelompok Quraisy. Padahal, jika ditelaah lebih dalam, alasan persyaratan al-Mawardi untuk mengangkat seorang khalifah Muslim dari kelompok Quraisy adalah bahwa kriteria seorang pemimpin untuk diterapkan di Indonesia masih dapat dilaksanakan.

Berdasarkan uraian di atas, penulis berpendapat bahwa pemimpin adalah orang yang memiliki kemampuan dan kelebihan yang diberi tanggung jawab untuk mengatur urusan agama dan dunia untuk mencapai tujuan bersama dalam suatu masyarakat. Oleh karena itu, non-muslim tidak memenuhi kualifikasi menjadi pemimpin karena mereka tidak bisa mengatur urusan agama Islam. Pemimpin dalam Islam secara umum tidak jauh berbeda dengan pemimpin pada umumnya. Artinya bahwa prinsip-prinsip pemimpin dalam Islam terdapat persamaan dengan prinsip pemimpin pada umumnya.

Dalam konteks pembahasan atau pemikiran Imam al-Mawardi mengenai nonmuslim yang berhak menduduki jabatan sebagai Wazir Tanfidzi dalam pemeritahan Islam dikarenakan jabatan ini memiliki wewenang yang lemah dan hanya 
Evan Edo Prasaetyo, Yono \& Sutisna

Kepemimpinan Non-Muslim Dalam Perspektif...

membutuhkan syarat yang sedikit. Pasalnya, kewenangannya masih dibatasi oleh pendapat dan gagasan Imam (khalifah). Wazir Tanfidzi hanya sebagai mediator antara khalifah dan rakyat.

Tugas dari Wazir Tanfidzi hanyalah melaksanakan perintah khalifah, merealisasikan titahnya, menindaklanjuti keputusannya, menginformasikan pelantikan pejabat, mempersiapkan pasukan, serta melaporkan informasi-informasi penting dan actual kepada khalifah supaya Ia dapat menanganinya sesuai perintah khalifah. Dengan demikian, Wazir Tanfidzi hanya berperan melaksanakan tugas dan tidak berhak melantik pejabat untuk menangani tugas tersebut. Jika ia dilibatkan dalam jajak pendapat, itu pun dalam kewenangan khusus. Akan tetapi, jika ia tidak dilibatkan dalam hal itu, kedudukannya lebih dari mediator atau duta.

Wazir Tanfidzi tidak membutuhkan pelantikan, tetapi sekadar pemberitahuan. Untuk menduduki jabatan ini, tidak disyaratkan harus merdeka dan berilmu karena Ia tidak memiliki wewenang untuk melantik pejabat yang mensyartkannya harus merdeka. Ia juga tidak diperbolehkan memberikan keputusan hukum sendiri yang mensyaratkannya harus berilmu. Tugas Wazir Tanfidzi (pembantu khalifah bidang administrasi) hanya terfokus pada dua hal, yakni mendampingi imam (khalifah) dan melaksanakan perintahnya.

Sebagai perbandingan, konsep kepemimpinan non-muslim juga dikonstrukksikan lewat pemikiran Ibnu Taimiyah. Serupa dengan Imam al-Mawardi pandangan ini juga ditengarai berpijak pada adanya fenomena kepemimpinan nonmuslim di tengah masyarakat yang mayoritas umat Islam. Ibnu Taimiyah, seorang pemikir Islam melaui pendapatnya yang paling terkenal dan kontroversial adalah "lebih baik dipimpin oleh pemimpin kafir yang adil, daripada dipimpin oleh pemimpin muslim yang dzalim" ${ }^{18}$ Berawal dari pendapat mengutamakan pemimpin yang adil dibandingkan keimanan ini, Ibnu Taimiyah melanjutkan lebih jauh tentang peranan negara dalam proyek kosmopolitanisme-nya. Ibnu Taimiyah mengemukakan tugas utama negara adalah tegaknya syari'at yang tidak lain demi tegaknya keadilan universal. Dengan demikian, menurutnya, syari'ah dan keadilan universal adalah "saudara kembar" yang paralel dan harus berjalan seiring. ${ }^{19}$

Meksipun demikian, diskursus seputar hukum mengangkat pemimpin nonmuslim di kalangan umat Islam merupakan isu kontroversial yang senantiasa memancing perdebatan di kalangan para ahli yang telah berlangsung sejak dahulu

18 Abu Tholib Khalik, "Pemimpin Non-Muslim dalam Perspektif Ibnu Taimiyah", Analisis: Jurnal Studi Keislaman, 14 no. 1 (2014): 59-89.

19 Abu Thobib Khalik. 78.

DIKTUM: Jurnal Syariah dan Hukum Volume 19 Nomor 1 Juli 2021 
Evan Edo Prasaetyo, Yono \& Sutisna

Kepemimpinan Non-Muslim Dalam Perspektif...

hingga kini. Hal ini muncul karena, baik dalam Al-Qur'an maupun al-Sunnah yang merupakan dua sumber utama hukum Islam, disamping ditemukan dalil-dalil yang melarang umat Islam memilih non-muslim sebagai pemimpinnya, ditemukan pula dalildalil lain yang bernada membolehkannya. ${ }^{20}$

\section{Kesimpulan}

Berdasarkan pembahasan yang telah diuraikan sebelumnya, dapat disimpulkan bahwa pemimpin dalam menurut Imam al-Mawardi adalah imamah dan syarat bagi orang yang berhak dipilih sebagai pemimpin dengan tujuh syarat yaitu, pertama, adil, kedua, memiliki ilmu yang luas untuk ijtihad, ketiga, sehat panca indera, keempat, sehat badan (jasmani), kelima, pandai mengendalikan urusan rakyat, keenam, berani dan tegas membela rakyat, wilayah dan Negara, ketujuh, memiliki nasab Quraisy. Adapun tipe pemimpin ideal adalah tipe pemimpin yang dicontohkan Rasulullah saw., karena beliau merupakan suri tauladan yang sempurna dengan akhlaq Al-Qur'an.

Konsep kepemimpinan seorang non-muslim dalam pemerintahan Islam menurut Imam al-Mawardi, sejatinya Imam al-Mawardi melarang seorang kafir (nonmuslim) menduduki jabatan sebagai pemimpin, karena itu bertentangan dengan syariat Islam. Imam al-Mawardi hanya membolehkan seorang kafirin atau nonmuslim menduduki jabatan dalam pemerintahan Islam hanya sebagai wazir atau setingkat menteri atau pembantu. Dengan kata lain, legitimasi kepemimpiann bagi non-muslim ada syaratnya untuk menduduki jabatan pada pemerintahan. Jabatan ini pun hanya boleh diberikan di wilayah kerja seorang Wazir Tanfidzi, yakni seorang pembantu khalifah bidang administrasi. Jabatan ini hanya mengurusi bidang mempersiapkan pasukan, menyampaikan informasi aktual kepada khalifah agar segera mendapat arahan untuk diselesaikan, menjalankan titah khalifah.

\section{Daftar Pustaka}

\section{Buku}

Al-Mawardi. al-Ahkam as-Sulthaniyyah, Jakarta: Qisthi Press, 2019.

Al-Qur'an dan Terjemahannya. Jakarta: Departemen Agama RI, 1987.

Khan, Mohammad Yaqub. A Political Study of Al-Mawardi with Special Reference to the Concept of Legitimicay. Leeds: University of Ledds, 2001.

Moleong, L.J. Metode Penelitian Kualitatif. Bandung: Rosdakarya, 2012.

20 Abu Thobib Khalik. 83.

DIKTUM: Jurnal Syariah dan Hukum Volume 19 Nomor 1 Juli 2021 
Evan Edo Prasaetyo, Yono \& Sutisna

Kepemimpinan Non-Muslim Dalam Perspektif...

\section{Artikel Jurnal}

Amin, Surahman \& Ferry Muhammadsyah Siregar, "Pemimpin dan Kepemimpinan Dalam Al-Qur'an", Tanzil: Jurnal Studi Islam 1 no.1. (2015):1-17.

Fauzan, Ahmad. “ Leadership Character According To Imam Al-Mawardi And Its Relevance In Indonesia: The Study Of The Book Of Al-Ahkam AsSulthaniyyah", Jurnal Penelitian, 15 no.01 (2018): 39-50.

Khalik, Abu Tholib. "Pemimpin Non-Muslim dalam Perspektif Ibnu Taimiyah", Analisis: Jurnal Studi Keislaman, 14 no. 1 (2014): 59-89.

Rahmawati. "Sistem Pemerintahan Islam Menurut Al-Mawardi dan Aplikasinya di Indonesia", Jurnal Syariah dan Hukum 16.no. 2 (2018): 264-283

Wahyudi, Hakim, Hakmi Hidayat \& Sri Wahyuni Hakim. "Pemikiran Gramatikal Bahasa Arab oleh Linguistic Arab (Studi Tokoh Lintas Mahzab Nahwu", Jurnal Ilmiah Keislaman 19 no.19 (2020): 113-128.

Zuhri, “Kepemimpinan Profetikdi Era 4.0", Jurnal Studi Ilmu Keagamaan Islam 1 no.1 (2020):115-135. 